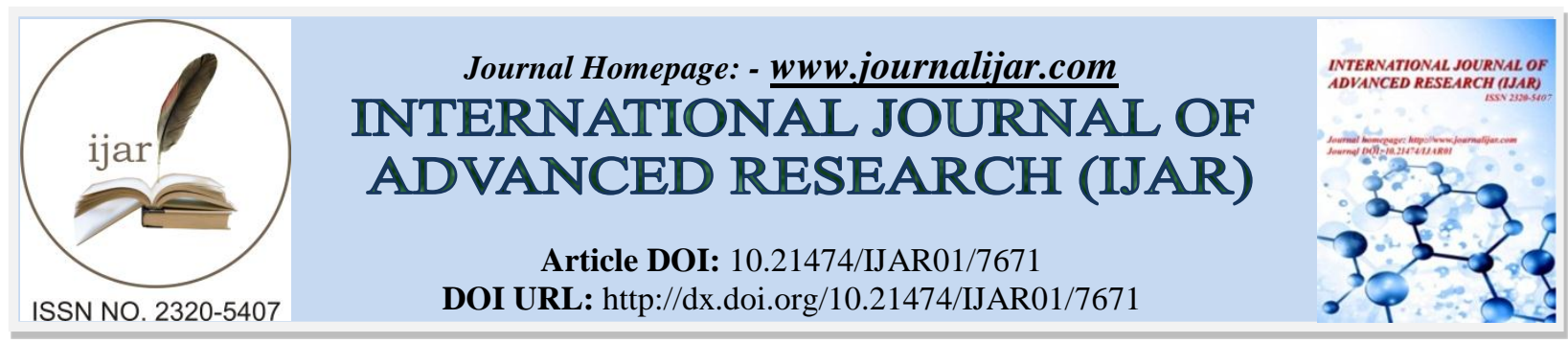

RESEARCH ARTICLE

\title{
POLICY IMPLEMENTATION AND STATUS PERFORMANCE OF STATE COLLEGES AND UNIVERSITIES IN REGION IV-A CALABARZON, PHILIPPINES.
}

\section{Rosario Gutierrez Catapang}

\section{Manuscript Info}

\section{Manuscript History}

Received: 05 July 2018

Final Accepted: 07 August 2018

Published: September 2018

\section{Keywords:-}

Management, education manager, status performance and policy implementation.

\section{Abstract}

In this age of change and innovations, the educational system of any society is in need of school managers who are not only efficient and effective, but also capable of designing and maintaining an environment conducive to the performance of individuals who are working together in groups towards the accomplishment of some preselected objectives (Koontz, cited by Lorenzana, 2011). This is the challenge that every education managers of today faces.

Most of the failures in any organization are attributed to ineffective leadership. It is also true in government agencies. Ironically, the need for managerial talent is more pressing to nation that are facing difficulties in economic development for most of " the chief problem is not the lack of knowledge about but how best to employ it"(Talingdan, 2010). One authority once said, "If any single factor in the key for unlocking the force of economic growth in the underdeveloped areas of the world, the factor is management" (Robock, 2011).

The recent policies for higher education, as well as the rapid technological and social changes, have placed new responsibilities on colleges and universities. This necessitates a serious look into the management aspect of academic institution so that they could fully contribute to the development of the society.

This study aimed to assess the policy implementation of the State Colleges and Universities in Region IV-A CALABARZON, Philippines in terms of instruction, faculty, facilities, research, and community extension. The status performance as to enrolment, attrition, graduation and board examination rate was also identified.

The writer holds the responsibility and willingness to show her findings in the effectiveness on policy implementation and status performance of the education managers in the area of management, supervision, faculty and human relations practices. It also hoped that the study may help to bring about the best quality education that each SUC aspire to provide to the people in Region IV-A CALABARZON, Philippines.

A model of best leadership practices for SUC's was developed based on the findings of this study.

Copy Right, IJAR, 2018,. All rights reserved. 


\section{Introduction:-}

University improvement and effectiveness have become major concern of education authorities, policy makers, administrators and teachers seeking to reform existing education systems. In many education systems there has emerged recognition that management-based self-assessment has potential to bring improvement in the quality of education. Consequently, education systems have undergone restructuring to establish "self-managing", "selfgoverning" or "self-determining university.

The state universities in Region IV-A CALABARZON are aiming for quality education since their thrust is to produce a globally competitive graduate in all their programs. The role of the institutions is to provide a wide variety of educational, training, research, continuing education and service programs to meet the personal and professional needs of citizens and employers. However, these can only be achieved if each state college or university can create their best performances in terms of enrolment, attrition, graduates and result of board examinations, as well as their policy implementation as to instruction, faculty, facilities, research and extension that will provide leadership, set policy, and advocate for transforming educational system to improve each citizen's quality of life and enhance global competitiveness.

\section{Objectives:-}

This study aims to describe the management of state colleges and universities in Region IV-A status performance and policy implementation. Specifically, it seeks to answer the following questions:

1. What is the level of implementation of policies in terms of instruction, faculty, facilities, research, and community extension?

2. What is the performance of State Universities and Colleges in terms of enrolment rate, attrition rate, graduation rate and board examination rate?

3. Is there a significant relationship between the level of implementation of policies, and the performance of State Universities and Colleges in CALABARZON?

\section{Methodology:-}

This study is both qualitative and quantitative in nature. It uses the descriptive method of research describing the management practices of selected colleges and universities. It was conducted in different state universities and colleges in Region IV-A CALABARZON. The respondents of the study includes 10 or 5 percent of administrators including the Vice-President for Academic Affairs, Vice-President for Finance, Vice-President for Administration, 15 or 9 percent directors wherein the campus director, Officer-in-charge, etc. are included, and 10 or 5 percent deans including the assistant deans, and officer-in-charge, and 150 and 81 percent faculty.

The standardized management assessment questionnaire based on AACCUP Manual, (2010) was the primary instrument in gathering the data. Unstructured interview as research instruments was also used.

Weighted Mean was used to assess the schools administrators' management practices as to instruction, faculty, facilities, research, and community extension. Pearson Product Moment Correlation was used to determine the degree of relationship between the level of implementation of policies, and the performance of the SUC's.

\section{Literature Review:-}

Managing is an increasingly important activity in today's complex society. Our society breeds more and more organizations every day. In each of these organizations, managing is an essential activity. Managers are constantly needed to plan, organize, direct, and control operations to ensure that organizations accomplish their goals, there is, and will continue to be, a demand for managers to do these jobs.

Managerial jobs, however, differ. Not all managers perform exactly the same activities or face the same problems. Because management is not closed system, all managers including education manager deal and interact with different environments-economics, technological, social, political, and ethical in which they operate. ( Lorenzana, C., 2011)

Management is a continuous process and not a program. This requires constant improvement in all the related policies, procedures and controls established by management. Do your research. Keep your ear to the market and 
make an effort to routinely revise all aspects of your operation. There should be a constant effort to improve proficiency - which will result in constant scopes for improvement. (Ramasamy, 2012)

Managerial development is often much more involved as such training is oriented toward both theory and practice. Some of the common approaches are lectures, programmed instruction, study courses, university courses, conferences and seminars. The responsibility for training and development of personnel rests primarily on the personnel's immediate manager. However, this should be carried on in coordination with the personnel department if such a department exist in the organization.. ( Medina, R. G. (2011).

The Manual of the Accrediting Agency of Chartered Colleges and Universities in the Philippines (AACCUP), Inc. (2010) states the following:

The curriculum and instruction occupy center stage in any educational program. The enhancement of the quality of these two allied areas deserves utmost consideration for they determine primarily the prestige and strength of the institution. Its areas of concern are encompassing. e.g. curricula and program of studies, learning opportunities, assessment, instructional materials, classroom management, academic performance of students, graduation requirements and administrative support for instruction.

The curriculum and program of studies must have content and design that will enable the students to achieve intended learning outcomes. It should work towards the pursuit of the mission of the institution, and the attainment of the course objectives. It should include recent developments of teaching and learning techniques, and professional practice e and take into account other attributes necessary for employment, such as teamwork, communication leadership skill, etc.

The instructional process should provide learning opportunities for the students. It should also make use of different strategies, methodologies and techniques. Learning opportunities could be in the following areas: 1) teaching and learning; 2) professional development; and 3) collaboration.

Requirements for graduation are made clear and well-known to the students. Research, practicum, on-the-job training and other activities prescribed in the curriculum as requirements for graduation should be strictly implemented to further improve quality of graduates.

The standard or quality of an institution or program is greatly measured by the qualifications of its faculty. In this light, the faculty should be composed of competent members in terms of academic qualifications, experience, and professional expertise. In addition, they should manifest desirable personal qualities and high level of professionalism. To be effective faculty members should be properly compensated and taken care of. They must be given opportunities for continuous personal and professional development. A policy of fair and equitable distribution of teaching assignment and workload should be practiced.

The quality and adequacy of the physical plant and facilities of a learning institution determine to a large measure the successful implementation of the curricular programs. In a broad sense, physical plant and facilities include school site that is located in a wholesome environment, safe from traffic and transportation hazard, sufficiently free from noise, dust, smoke, and other undesirable elements. The campus should be so planned that it would be adequate for the intellectual, social, physical and cultural interest of the institution. The size and number of the classroom should be sufficient to accommodate the student population. It should be equipped with the required furniture, lighting, ventilation, and other related materials. Other facilities like, assembly and athletic facilities, medical and dental clinic, student center, and food service unit must be available.

Research is an avenue through which new knowledge is discovered, applied or verified and through which appropriate technologies are generated. Thus, it is a basic requirement for an educational institution to have a firmly established research and development program. The institutional leadership in research should be proactive and developmental in orientation. It must provide adequate and sustained budget allocation annually for the College. Adequate physical facilities, laboratory equipment and supplies for research should be provided.

The extension function makes the institution's presence felt in the community. It involves the application of existing knowledge and technology and those generated in the institution to improve the quality of life of the people, through 
the extension program, people are empowered with appropriate knowledge, attitudes, and skills. Thus, extension services cater to various aspects of the community life, e.g., economic growth, promotion of health, environmental management, and social transformation.

The institution plans and implements an extension program that is need and client-based. This program should have budgetary support and other resources allocation. The faculty members may serve as organizer, facilitators, coordinators, service providers, and change agents in the community as forms of extension and community involvement.

The Philippines envisions its higher education system to be the key player in the education and integral formation of professionally competent, service oriented, principled and productive citizens, hence it is expected to become the prime mover of the nation's socio-economic growth and sustainable development. Directed by this vision, the higher education system should offer programs and services that meet the demands of industrializing economy within the context development and a culture of peace, as well as the challenges of a diverse and globalized society. (Garcia, 2004) This can only be realized through education institutions having the effective policy implementation and management performance.

\section{Discussion:-}

Table 1:-Presents the implementation of policies as to Instruction of the SUCs in CALABARZON

\begin{tabular}{|c|c|c|c|c|c|c|c|c|}
\hline \multirow[t]{2}{*}{ Instruction } & \multicolumn{2}{|c|}{ Administrator } & \multicolumn{2}{|c|}{ Director } & \multicolumn{2}{|l|}{ Dean } & \multicolumn{2}{|c|}{ Faculty } \\
\hline & Mean & VI & Mean & VI & Mean & VI & Mean & VI \\
\hline $\begin{array}{l}\text { Provide education for the intellectual, ethical, } \\
\text { physical, emotional, and social growth of all } \\
\text { students }\end{array}$ & 3.67 & FI & 3.48 & I & 3.52 & FI & 3.56 & FI \\
\hline Allow students to develop their full potentials & 3.39 & I & 3.72 & FI & 3.51 & I & 3.53 & FI \\
\hline $\begin{array}{l}\text { Provide curriculum offered to all students in } \\
\text { the basic disciplines and the arts, at all levels, } \\
\text { and should be rich, stimulating, and } \\
\text { challenging }\end{array}$ & 3.47 & I & 3.61 & FI & 3.63 & FI & 3.54 & FI \\
\hline $\begin{array}{l}\text { Provide instructional program of the public } \\
\text { schools to be among its highest priorities }\end{array}$ & 3.48 & I & 3.58 & FI & 3.67 & I & 3.38 & I \\
\hline $\begin{array}{l}\text { Ensure that educational goals and objectives } \\
\text { to meet the needs of students }\end{array}$ & 3.36 & $\mathrm{I}$ & 3.47 & I & 3.64 & FI & 3.49 & $\mathrm{I}$ \\
\hline $\begin{array}{l}\text { Provide personnel, equipment, instructional } \\
\text { supplies and materials, and other support } \\
\text { required to meet professional teaching staff } \\
\text { needs }\end{array}$ & 3.47 & I & 3.49 & $\mathrm{I}$ & 3.63 & FI & 3.66 & FI \\
\hline $\begin{array}{l}\text { Develop instruction that is designed to meet } \\
\text { individual needs }\end{array}$ & 3.42 & I & 3.42 & $\mathrm{I}$ & 3.87 & FI & 3.80 & FI \\
\hline Ensure achievement of the curriculum & 3.56 & $\mathrm{I}$ & 3.61 & FI & 3.48 & $\mathrm{I}$ & 3.51 & $\mathrm{I}$ \\
\hline Over-all Mean & 3.48 & $\mathrm{I}$ & 3.55 & FI & 3.62 & FI & 3.56 & FI \\
\hline
\end{tabular}

Data reveals that the administrators assessed that the SUCs fully implemented social growth of all students as seen from the mean score of 3.67, while the directors assessed that there was full implementation on allowing students to develop their full potentials as seen from the mean score of 3.72, but the Dean and faculty assessed that the university fully implemented the development of instruction that is designed to meet individual needs as indicated from the mean score of 3.87 and 3.80 respectively. 
Table 2:-Presents the implementation of policies as to Faculty of the SUCs in CALABARZON

\begin{tabular}{|c|c|c|c|c|c|c|c|c|}
\hline \multirow[t]{2}{*}{ Faculty } & \multicolumn{2}{|c|}{ Administrator } & \multicolumn{2}{|c|}{ Directors } & \multicolumn{2}{|l|}{ Dean } & \multicolumn{2}{|c|}{ Faculty } \\
\hline & Mean & VI & Mean & VI & Mean & VI & Mean & VI \\
\hline Teachers have the required area of specialization & 3.40 & $\mathrm{I}$ & 3.46 & $\mathrm{I}$ & 3.74 & FI & 3.53 & FI \\
\hline Meet the required educational qualifications & 3.16 & I & 3.45 & $\mathrm{I}$ & 3.55 & FI & 3.39 & $\mathrm{I}$ \\
\hline $\begin{array}{l}\text { Attained the appropriate graduate degree relevant } \\
\text { to the subject teaching }\end{array}$ & 3.34 & $\mathrm{I}$ & 3.41 & I & 3.57 & FI & 3.41 & I \\
\hline Passed the licensure exam or equivalent & 3.61 & FI & 3.43 & $\mathrm{I}$ & 3.68 & FI & 3.49 & FI \\
\hline $\begin{array}{l}\text { Attained satisfactory rating in teaching } \\
\text { performance }\end{array}$ & 3.52 & $\mathrm{I}$ & 3.78 & FI & 3.64 & FI & 3.54 & $\mathrm{I}$ \\
\hline Physically, morally, and emotionally fit to teach & 3.52 & $\mathrm{I}$ & 3.44 & $\mathrm{I}$ & 3.69 & FI & 3.58 & FI \\
\hline $\begin{array}{l}\text { Writes instructional materials for classroom } \\
\text { instruction }\end{array}$ & 3.39 & $\mathrm{I}$ & 3.53 & FI & 3.72 & FI & 3.51 & FI \\
\hline $\begin{array}{l}\text { Member of at least one professional } \\
\text { organization/societies related to the program he/she } \\
\text { is teaching }\end{array}$ & 3.45 & I & 3.34 & $\mathrm{I}$ & 3.39 & I & 3.47 & I \\
\hline Over-all Mean & 3.42 & $\mathrm{I}$ & 3.48 & $\mathrm{I}$ & 3.63 & FI & 3.49 & $\mathrm{I}$ \\
\hline
\end{tabular}

It can be seen from the table that the administrators assessed that the SUCs fully implemented the policies on hiring faculty who passed the licensure exam or equivalent as described from the mean score of 3.61, the directors, on the other hand, assessed that there was full implementation on attaining satisfactory rating in teaching performance as indicated from the mean score of 3.7. The Deans assessed that there was also full implementation on the policy that teachers to be hired have the required area of specialization as described from the mean score of 3.74, and the faculty members assessed that the university fully implemented the policy that teachers need to be physically, morally, and emotionally fit to teach based on the mean score of 3.58 .

Results of the interviews revealed that the teachers are keeping abreast with the latest trends in teaching. The basic strategies cannot always be left behind like the use of various type of teaching approaches and specific kind of activity particularly involving the methods, processes, procedures and techniques relative to the instruction of the university.

Table 3:-Depicts the level of implementation of policies as to facilities of the SUCs in CALABARZON

\begin{tabular}{|c|c|c|c|c|c|c|c|c|}
\hline \multirow[t]{2}{*}{ Facilities } & \multicolumn{2}{|c|}{ Administrator } & \multicolumn{2}{|c|}{ Directors } & \multicolumn{2}{|l|}{ Dean } & \multicolumn{2}{|c|}{ Faculty } \\
\hline & Mean & VI & Mean & VI & Mean & VI & Mean & $\mathrm{VI}$ \\
\hline $\begin{array}{l}\text { All use of school facilities must be } \\
\text { accompanied by an approved request for use }\end{array}$ & 3.41 & I & 3.57 & FI & 3.40 & I & 3.46 & $\mathrm{I}$ \\
\hline $\begin{array}{l}\text { Payment for school facilities along with } \\
\text { estimated custodial and equipment fees must } \\
\text { be made in advance of the first use date }\end{array}$ & 3.43 & I & 3.68 & FI & 3.16 & I & 3.45 & I \\
\hline $\begin{array}{l}\text { Encourage the administrator safety } \\
\text { precautions in the building, cleaning of the } \\
\text { building after its use, and for any services } \\
\text { required by the renter in accordance with the } \\
\text { use of the facilities approved }\end{array}$ & 3.44 & I & 3.69 & FI & 3.55 & FI & 3.39 & $\mathrm{I}$ \\
\hline $\begin{array}{l}\text { Ensure that the custodian on duty shall be } \\
\text { responsible for the supervision of the } \\
\text { building and equipment }\end{array}$ & 3.54 & I & 3.58 & FI & 3.51 & $\mathrm{FI}$ & 3.52 & FI \\
\hline Over-all Mean & 3.46 & $\mathrm{I}$ & 3.63 & FI & 3.41 & $\mathrm{I}$ & 3.46 & $\mathrm{I}$ \\
\hline
\end{tabular}

It was found out that the administrators and faculty members assessed that the SUCs fully implemented the assurance that the custodian on duty shall be responsible for the supervision of the building and equipment as seen from the mean score of 3.54 and 3.52 respectively, while the directors and deans assessed that there was full implementation on encouraging the administrator safety precautions in the building, cleaning of the building after its use as reflected from the mean score of 3.69 and 3.55 respectively. 
As stated by Timothy (2008) effective school facility planning produces an environment in which teachers can teach and students can learn effectively and efficiently. As the largest tool of instruction, the school facility may either enhance or detract from the educational program. The school facility strongly impacts the educational program; it is not just housing. A well-designed facility will enhance the program by supporting the instructional design and providing a warm, dynamic setting in which to provide educational experiences.

Table 4:-Displays the level of implementation of policies as to research of the SUCs in CALABARZON

\begin{tabular}{|l|l|l|l|l|l|l|l|l|l|l|}
\hline \multirow{2}{*}{ Research } & \multicolumn{2}{|l|}{ Administrator } & Director & \multicolumn{2}{l|}{ Dean } & & \multicolumn{2}{l|}{ Faculty } \\
\cline { 2 - 9 } & Mean & VI & Mean & VI & Mean & VI & Mean & VI \\
\hline $\begin{array}{l}\text { Conduct at least one research forum } \\
\text { within the academic year }\end{array}$ & 3.78 & I & 3.66 & FI & 3.81 & FI & 3.71 & FI \\
\hline $\begin{array}{l}\text { Publish at least one research work in a } \\
\text { Journal once a year }\end{array}$ & 3.69 & FI & 3.63 & FI & 3.68 & FI & 3.52 & FI \\
\hline $\begin{array}{l}\text { Conduct research that can help in the } \\
\text { realization of school vision, mission and } \\
\text { goals }\end{array}$ & 3.59 & FI & 3.53 & FI & 3.69 & FI & 3.75 & FI \\
\hline $\begin{array}{l}\text { Encourage critical discussion on the } \\
\text { social and cultural implications of } \\
\text { research activities }\end{array}$ & 3.61 & FI & 3.57 & FI & 3.59 & FI & 3.73 & FI \\
\hline $\begin{array}{l}\text { Uphold the virtue of intellectual integrity } \\
\text { and honesty in research }\end{array}$ & 3.82 & FI & 3.78 & I & 3.66 & FI & 3.46 & I \\
\hline Over-all Mean & 3.69 & FI & 3.63 & FI & 3.69 & FI & 3.62 & FI \\
\hline
\end{tabular}

Findings revealed that the administrators and directors assessed that the SUCs fully implemented the policy of upholding the virtue of intellectual integrity and honesty in research as indicated from the mean score of 3.82 and 3.78 respectively, while the Dean assessed that there was full implementation in conducting at least one research forum within the academic year as seen from the mean score of 3.81, but the faculty members assessed that there was also full implementation of conducting research that can help in the realization of university vision, mission and goals based on the means score of 3.75 .

Table 5:-Depicts the level of implementation of policies as to community extension of the SUCs in CALABARZON.

\begin{tabular}{|l|l|l|l|l|l|l|l|l|l|l|}
\hline Community Extension & \multicolumn{2}{l|}{ Administrator } & \multicolumn{2}{l|}{ Directors } & \multicolumn{2}{l|}{ Dean } & \multicolumn{2}{l|}{ Faculty } \\
\cline { 2 - 10 } & Mean & VI & Mean & VI & Mean & VI & \multicolumn{2}{l|}{ Mean } & VI \\
\hline $\begin{array}{l}\text { Require teachers to conduct at least one extension } \\
\text { service a year }\end{array}$ & 3.59 & FI & 3.73 & FI & 3.66 & FI & 3.66 & FI \\
\hline $\begin{array}{l}\text { Present extension research output in a forum locally } \\
\text { or internationally }\end{array}$ & 3.55 & FI & 3.69 & FI & 3.62 & FI & 3.63 & FI \\
\hline $\begin{array}{l}\text { Mobilize the university constituency for meaningful } \\
\text { and responsive community service }\end{array}$ & 3.68 & FI & 3.52 & FI & 3.65 & FI & 3.53 & FI \\
\hline $\begin{array}{l}\text { Serve as a link/channel between the different units of } \\
\text { the University and partner agencies, interest groups } \\
\text { and individuals, especially on extension matters }\end{array}$ & 3.53 & FI & 3.46 & I & 3.48 & I & 3.57 & FI \\
\hline $\begin{array}{l}\text { Encourage teachers to require students to come up } \\
\text { with an extension research output as a class } \\
\text { requirement }\end{array}$ & 3.57 & FI & 3.40 & I & 3.68 & FI & 3.16 & I \\
\hline Over-all Mean & & & & & & & & \\
\hline
\end{tabular}

The administrators assessed that the SUCs fully implemented the mobilization of the university constituency for meaningful and responsive community service as seen from the mean score of 3.68. The directors and faculty members, on the other hand, assessed that there were full implementation on requiring teachers to conduct at least one research a year as seen from the mean score of 3.73 and 3.66 respectively, but the Deans assessed that there was also full implementation on encourage teachers to require students to come up with an extension research output as a class requirement based on the mean score of 3.68 . 
Because knowledge is such a powerful element in the shaping process, educational programs that create knowledge are one of the most important activities in any community. In communities all across the country, extension, through its educational programs, plays a significant role in the knowledge-creation process and therefore is instrumental in shaping communities.

Table 6:-Depicts the performance of State, Universities and Colleges (SUCs) for the past three years as to enrollment rate

\begin{tabular}{|c|c|c|c|c|c|c|c|c|c|c|}
\hline \multirow[t]{2}{*}{ School Year } & \multicolumn{2}{|l|}{ SUC 1} & \multicolumn{2}{|l|}{ SUC 2} & \multicolumn{2}{|l|}{ SUC 3} & \multicolumn{2}{|l|}{ SUC 4} & \multicolumn{2}{|l|}{ SUC 5} \\
\hline & Enrolled & Rate & Enrolled & Rate & Enrolled & Rate & Enrolled & Rate & Enrolled & Rate \\
\hline $2010-2011$ & 2098 & & 2304 & & 2424 & & 2537 & & 2592 & \\
\hline $2011-2012$ & 2134 & 16.8 & 2463 & 6.5 & 2491 & 2.7 & 2565 & 1.1 & 2619 & 1.0 \\
\hline $2012-2013$ & 2576 & 17.2 & 2623 & 6.9 & 2648 & 5.9 & 2704 & 5.1 & 2788 & 6.1 \\
\hline $2013-2014$ & 3218 & 19.9 & 3302 & 20.5 & 3365 & 21.3 & 3418 & 20.9 & 3501 & 20.4 \\
\hline $\begin{array}{l}\text { Average } \\
\text { Enrollment } \\
\text { Rate }\end{array}$ & 17.96 & & 11.03 & & 9.9 & & 9.0 & & 9.2 & \\
\hline Rank & 1 & & 2 & & 3 & & 5 & & 4 & \\
\hline
\end{tabular}

SUC 1 has an average enrollment rate of $17.96 \%$, while SUC 2 has 11.03 percent, SUC 3 has 9.9 percent, SUC 4 has 9.0 percent, and SUC 4 has an average enrollment rate of 9.2 percent for the past three years. SUC 1, 2, 3, 5 and 4 ranked first, second, third, fourth, and fifth respectively in terms of increase in enrolment rate.

Table 7:-Depicts the performance of State, Universities and Colleges (SUCs) for the past three years as to attrition rate.

\begin{tabular}{|c|c|c|c|c|c|c|c|c|c|c|}
\hline \multirow[t]{2}{*}{ School Year } & \multicolumn{2}{|l|}{ SUC 1} & \multicolumn{2}{|l|}{ SUC 2} & \multicolumn{2}{|l|}{ SUC 3} & \multicolumn{2}{|l|}{ SUC 4} & \multicolumn{2}{|l|}{ SUC 5} \\
\hline & $\begin{array}{l}\text { Number } \\
\text { of } \\
\text { Students } \\
\text { Dropped }\end{array}$ & Rate & $\begin{array}{l}\text { Number of } \\
\text { Students } \\
\text { Dropped }\end{array}$ & Rate & $\begin{array}{l}\text { Number } \\
\text { of } \\
\text { Students } \\
\text { Dropped }\end{array}$ & Rate & $\begin{array}{l}\text { Number } \\
\text { of } \\
\text { Students } \\
\text { Dropped }\end{array}$ & Rate & $\begin{array}{l}\text { Number } \\
\text { of } \\
\text { Students } \\
\text { Dropped }\end{array}$ & Rate \\
\hline $\begin{array}{l}2010- \\
2011\end{array}$ & 137 & & 151 & & 153 & & 158 & & 160 & \\
\hline $\begin{array}{l}2011- \\
2012\end{array}$ & 142 & 3.5 & 157 & 3.8 & 160 & 4.4 & 163 & 3.1 & 165 & 3.0 \\
\hline $\begin{array}{l}2012- \\
2013\end{array}$ & 150 & 5.3 & 160 & 1.9 & 165 & 3.0 & 172 & 5.2 & 175 & 5.7 \\
\hline $\begin{array}{l}2013- \\
2014\end{array}$ & 161 & 6.9 & 168 & 4.8 & 170 & 2.9 & 174 & 1.1 & 175 & 0 \\
\hline Total & 5.2 & & 3.5 & & 3.4 & & 3.1 & & 2.9 & \\
\hline Rank & 1 & & 2 & & 3 & & 4 & & 5 & \\
\hline
\end{tabular}

It was found out that for the past three years, SUC 1 has an average attrition rate of 5.2 percent, SUC 2 has an average of 3.5 percent, SUC 3 has 3.4 percent, SUC 4 has 3.1 percent while SUC 5 has an average attrition rate of 2.9 percent. SUC 1, 2, 3, 4, and 5 ranked first, second, third, fourth and fifth in terms of attrition rate.

Table 8:-Depicts the performance of State, Universities and Colleges (SUCs) for the past three years as to graduation rate.

\begin{tabular}{|c|c|c|c|c|c|c|c|c|c|c|}
\hline \multirow[t]{2}{*}{ School Year } & \multicolumn{2}{|l|}{ SUC 1} & \multicolumn{2}{|l|}{ SUC 2} & \multicolumn{2}{|l|}{ SUC 3} & \multicolumn{2}{|l|}{ SUC 4} & \multicolumn{2}{|l|}{ SUC 5} \\
\hline & $\begin{array}{l}\text { Gradua } \\
\text { ted }\end{array}$ & Rate & $\begin{array}{c}\text { Gradua } \\
\text { ted }\end{array}$ & Rate & $\begin{array}{l}\text { Gradua } \\
\text { ted }\end{array}$ & Rate & $\begin{array}{l}\text { Gradua } \\
\text { ted }\end{array}$ & Rate & $\begin{array}{l}\text { Gradua } \\
\text { ted }\end{array}$ & Rate \\
\hline $2010-2011$ & 1961 & & 2153 & & 2271 & & 2379 & & 2432 & \\
\hline $2011-2012$ & 1992 & 1.6 & 2306 & 6.6 & 2331 & 2.6 & 2402 & 0.95 & 2454 & 0.89 \\
\hline $2012-2013$ & 2426 & 17.9 & 2463 & 6.4 & 2483 & 6.1 & 2532 & 5.1 & 2613 & 6.1 \\
\hline $2013-2014$ & 3057 & 20.6 & 3134 & 21.4 & 3195 & 22.3 & 3244 & 21.9 & 3326 & 20.4 \\
\hline $\begin{array}{l}\text { Average } \\
\text { Enrollment }\end{array}$ & 13.4 & & & & 10.3 & & 9.3 & & & \\
\hline
\end{tabular}




\begin{tabular}{|l|l|l|l|l|l|}
\hline Rate & & 11.5 & & & 9.5 \\
\hline Rank & 1 & 2 & 3 & 5 & 4 \\
\hline
\end{tabular}

Data reveals that for the past three years SUC 1 has an average graduation rate of 13.4 percent, SUC 2 has 11.5 percent, SUC 3 has 10.3 percent, SUC 4 has 9.3 percent, while SUC 5 has an average enrollment rate of 9.5 percent. SUC 1, 2, 3, 5 and 4 ranked first, second, third, fourth, and fifth in terms of graduation rate.

Table 9:-Depicts the performance of State Universities and Colleges (SUCs) as to Board Examination

\begin{tabular}{|c|c|c|c|c|c|c|c|c|c|c|}
\hline \multirow{2}{*}{ School Year } & \multicolumn{2}{|c|}{ SUC 1 } & \multicolumn{2}{c|}{ SUC 2 } & \multicolumn{2}{c|}{ SUC 3 } & \multicolumn{2}{c|}{ SUC 4 } & \multicolumn{2}{c|}{ SUC 5 } \\
\cline { 2 - 11 } & Enrolled & Rate & Enrolled & Rate & Enrolled & Rate & Enrolled & Rate & Enrolled & Rate \\
\hline $\begin{array}{c}2010- \\
2011\end{array}$ & 812 & & 700 & & 600 & & 623 & & 640 & \\
\hline $\begin{array}{c}2011- \\
2012\end{array}$ & 900 & 9.7 & 789 & 11.1 & 691 & 13.1 & 684 & 8.9 & 732 & 12.5 \\
\hline $\begin{array}{c}2012- \\
2013\end{array}$ & 948 & 5.1 & 824 & 4.2 & 742 & 19.1 & 700 & 2.2 & 768 & 4.7 \\
\hline $\begin{array}{c}2013- \\
2014\end{array}$ & 987 & 3.9 & 986 & 16.4 & 871 & 14.8 & 732 & 4.3 & 892 & 13.9 \\
\hline $\begin{array}{c}\text { Board } \\
\text { Examination }\end{array}$ & 6.23 & 10.57 & \multicolumn{2}{|c|}{15.67} & & 5.13 & & 10.36 \\
\hline Rank & 4 & \multicolumn{2}{|c|}{2} & \multicolumn{2}{|c|}{1} & \multicolumn{2}{|c|}{5} & & 3 \\
\hline
\end{tabular}

SUC 1 has a board examination rate of 6.23 percent, while SUC 2 has 10.57 percent, SUC 3 has 15.67 percent, SUC 4 has 5.13 percent, and SUC 4 has an average enrollment rate of 10.36 percent for the past three years. SUC 3, 2, 5, 1 , and 4 ranked first, second, third, fourth, and fifth respectively.

Table 10:-Significant Relationship between the policy implementation and status performance of SUCs in CALABARZON

\begin{tabular}{|l|l|c|c|c|c|c|c|}
\hline & \multicolumn{1}{|c|}{$\begin{array}{c}\text { SUC's } \\
\text { Performance }\end{array}$} & \multirow{2}{*}{$\begin{array}{c}\text { Spearman's } \\
\mathbf{r}\end{array}$} & Correlation & \multicolumn{2}{|c|}{$\mathbf{t}$} & Remarks & Decision \\
\cline { 5 - 8 } & Enrollment rate & 0.81 & High Corr & 1.89 & 1.734 & Reject & Significant \\
\cline { 2 - 7 } & Attrition rate & 0.77 & High Corr & 1.81 & 1.734 & Reject & Significant \\
\cline { 2 - 7 } & Graduation rate & 0.35 & Low Corr & 1.58 & 1.734 & Accept & $\begin{array}{c}\text { Not } \\
\text { Significant }\end{array}$ \\
\cline { 2 - 7 } $\begin{array}{l}\text { Level of } \\
\text { implementation } \\
\text { policies }\end{array}$ & $\begin{array}{l}\text { Board } \\
\text { Examination rate }\end{array}$ & 0.79 & High Corr & 1.76 & 1.734 & Reject & Significant \\
\hline
\end{tabular}

There is significant relationship between the level of implementation of policies, and the SUC's enrollment rate, the attrition rate, and the board examination rate while there is no significant relationship between the level of implementation of policies and the SUC's graduation rate.

\section{Conclusions:-}

Based on the findings from this study, the following conclusions are drawn:

1. The administrators, director, deans and faculty members assessed the management status of the five State Universities and Colleges (SUC) for the past three years from 2011-2014 was implemented in terms of instruction, faculty, facilities, research, and community extension.

2. The policies concerning the instruction, faculty, facilities, research, and community extension are implemented in the five State Universities and Colleges (SUC) for the past three years from 2011-2014.

3. The five State Universities and Colleges (SUC) for the past three years from 2011-2014 is performing well as measured in terms of enrollment rate, attrition rate, graduation rate, and board examination rate. 
4. There is a significant relationship between the level of implementation of policies, and the performance of the SUC's as to enrollment rate, attrition rate, and board examination, but no significant relationship between graduation rate.

5. A model of best leadership practices for SUC's was developed based on the findings of this study.

\section{Recommendations:-}

Based on the findings and conclusion of this study, the researcher proposes the following recommendations:

1. Encourage school administrators to utilize the findings of this study in improving areas that were found weak but strengthen more the areas which were found strong particularly in areas of instruction, faculty, facilities, research, and community extension.

2. Develop strategies that will improve the performance of the SUC's in terms of enrolment rate, board examination, and lessen the attrition rate.

3. Consider the use of the proposed model for best leadership practices among SUC's.

\section{References:-}

1. Lorenzana, C, (2012) "Management Theory and Practice"

Revised Edition. Manila: Rex Publishing Co.

2. Medina, R. G. (2011). "Human Behavior in Organization" Manila: Rex Publishing Co.

3. Ramasamy S. (2012), “Total Quality Management" New Delhi: Tata McGraw-Hill Publishing Company Limited.

4. Talingdan, Arsenio P. (2010),"Public Administration and Management in the Philippines," Quezon City: Alemar Phoenix Publishing House.

5. Kenny, J.D, Managing a Modern University: Is It Time for a Rethink?, Higher Education Research and Development, 28, (6) pp. 629-642. ISSN 0729-4360 (2009)

6. Robock, S. H.,(2005),'Strategies for Regional Economic Development”. Papers in Regional Science, 17: 129141. doi: 10.1111/j.1435-5597.1966.tb01345.

7. Manual of the Accrediting Agency of Chartered Colleges and Universities in the Philippines (AACCUP), Inc. (2010) 